\title{
Hepatic Mass
}

National Cancer Institute

\section{Source}

National Cancer Institute. Hepatic Mass. NCI Thesaurus. Code C35294.

A space-occupying pathologic process that affects the liver parenchyma. 